\title{
O wydawnictwie słownikowym z zakresu biografistyki księgoznawczej
}

W sierpniu 2016 r. trafił do rąk czytelników Suplement IV do Stownika pracowników ksiażki polskiej. Realizatorem edycji jest profesjonalne Wydawnictwo Stowarzyszenia Bibliotekarzy Polskich (dalej SBP); Suplement ukazał się w serii „Nauka-Dydaktyka-Praktyka” jako jej 171 pozycja, opracowana redakcyjnie przez zespół w składzie: Magdalena Rzadkowolska (przewodnicząca), Hanna Tadeusiewicz, Agata Walczak-Niewiadomska (sekretarz), działający w Pracowni Słownika pracowników książki polskiej przy Katedrze Bibliotekoznawstwa i Informacji Naukowej Uniwersytetu Łódzkiego (dalej BiIN UŁ). Recenzję wydawniczą Suplementu sporządziła prof. dr hab. Elżbieta Umińska-Tytoń. Tom był finansowany w ramach Narodowego Programu Rozwoju Humanistyki w latach 2012-2016 oraz dofinansowany przez Wydział Filologiczny UŁ.

Obszerny tom liczy $364 \mathrm{~s}$. dwuszpaltowego druku, jest uzupełniony o indeks alfabetyczny osób i instytucji związanych z książką, zawiera 496 biogramów autorstwa 140 osób. Hasła łączy system symboli graficznych (gwiazdki i strzałki - ich znaczenie objaśniono we Wstępie ${ }^{2}$ ), każdy życiorys opatrzono bibliografią załącznikową i nazwiskiem autora. Do książki dołączono płytę z tekstem Suplementu IV.

Metoda przygotowania biogramów do druku, wypracowana w tomie pierwszym z 1972 r. ${ }^{3}$, nie zmieniła się ani pod względem merytorycznym ani formalnym, stale obowiązywała instrukcja dla autorów i redaktorów pióra dr Ireny Treichel, zachowano również zakres tematyczny i zasięg chronologiczny, a także ustalone wówczas zasady opisu bibliograficznego. Tyle podstawowych informacji o nowo wydanym kolejnym Suplemencie do Stownika pracowników książki polskiej, który funkcjonuje w środowisku bibliologów i bibliotekarzy, ogólnie - humanistów różnych specjalności - już od 45 lat i może warto przy tej okazji przybliżyć pokrótce - zwłaszcza młodemu pokoleniu - dzieje tego przedsięwzięcia.

\footnotetext{
Słownik pracowników książki polskiej. Suplement IV, red. M. Rzadkowolska, Warszawa 2016. Zob. Redakcja, Wstęp, [w:] tamże, s. 5.

Zob. Stownik pracowników książi polskiej, red. I. Treichel, Warszawa-Łódź 1972.
} 
Koncepcja przygotowania słownika biograficznego pracowników książki polskiej sięga czasów drugiej wojny światowej i wiąże się z osobą doc. Adama Łysakowskiego, który zlokalizował prace w działającym od $1946 \mathrm{r}$. w Łodzi Państwowym Instytucie Książki; wkrótce - po zlikwidowaniu PIK-u w 1949 r. przejęła je Biblioteka Uniwersytetu im. Mikołaja Kopernika w Toruniu. Kierował nimi w latach 1954-1958 doc. Ksawery Świerkowski ${ }^{4}$. Prace przygotowawcze podjęły niezależne od siebie zespoły powołane w bibliotekach uniwersyteckich, w bibliotekach Polskiej Akademii Nauk (dalej PAN) we Wrocławiu (Ossolineum) i Gdańsku oraz w Książnicy Miejskiej w Toruniu. W 1958 r. ukazał się Zeszyt próbny Słownika ${ }^{5}$ i w tymże roku rozproszone prace połączono w powołanej Redakcji w Oddziale Prac Naukowych Biblioteki Uniwersyteckiej w Łodzi (dalej BUŁ). Pracami kierowała Redakcja (trzy osoby) oraz Komitet Redakcyjny (18 osób), w skład którego weszli m.in. przewodniczący zespołów pozałódzkich. Funkcję redaktora naczelnego objęła w 1961 r. I. Treichel, starszy kustosz dyplomowany BUŁ. Działaniom patronowała Komisja do Spraw Bibliotek Rady Głównej Szkolnictwa Wyższego, a prowadzone były w ramach „Porozumienia z Państwowym Wydawnictwem Naukowym w Warszawie" (dalej PWN). W 1962 r. opublikowano Wykaz haset do Stownika (ok. 3200 nazwisk) ${ }^{6}$. W toku prac organizacyjnych i redakcyjnych tworzono, stale poszerzany, warsztat Stownika (kilka kartotek, archiwum, materiały ikonograficzne i inne), bardzo ułatwiający przeprowadzenie przedsięwzięcia. W 1964 r. do łódzkiej Redakcji weszła mgr (obecnie profesor) H. Tadeusiewicz i do dziś w niej pozostaje $\mathrm{e}^{7}$. Ważną sprawą dla planowanej publikacji był dobór haseł i ich objętość oraz pozyskanie kompetentnych autorów. Redakcja i członkowie Komitetu Redakcyjnego nawiązali kontakty z instytucjami i organizacjami związanymi z książką, wykorzystywali osobiste znajomości, aby zapewnić najlepszych specjalistów - badaczy i praktyków, którzy podjęli się przygotowania autorskiego haseł. Pozyskane biogramy podlegały następnie opracowaniu redakcyjnemu, a przed włączeniem do Stownika - autoryzacji ostatecznej wersji tekstów.

Przebieg i postęp prac był m.in. przedmiotem obrad Komitetu Redakcyjnego, którego członkowie spotykali się wielokrotnie w Łodzi i współpracujących ośrodkach uniwersyteckich, wrocławskim Ossolineum, Bibliotece

4 Zob. K. Świerkowski, Stownik biograficzny pracowników ksiązki polskiej, Wrocław 1957 [odb.].

Zob. Stownik pracowników książki polskiej. Zeszyt próbny, red. K. Świerkowski, W. Pawlikowski, I. Treichel, Łódź 1958.

6 Zob. Stownik biograficzny pracowników książki polskiej. Wykaz hasel, Łódź 1962 [powiel.].

Zob. m.in. Hanna Tadeusiewicz - bibliotekarz i bibliolog. Bibliografia publikacji 1966-2004, oprac. E. Andrysiak, Kalisz 2004; Profesor Hanna Tadeusiewicz, [red. Z. M. Wichowa], Łódź 2010, „Sylwetki Łódzkich Uczonych”, z. 101. 
Gdańskiej PAN, Książnicy Miejskiej w Toruniu oraz innych placówkach, co integrowało zespół i ułatwiało jego działania. Zakończono je w marcu 1970 r. - przesłano wówczas do Oddziału Łódzkiego PWN pierwszą partię maszynopisu, a w lipcu 1971 r. całość skierowano do drukarni w Łodzi. Pozostała jeszcze korekta odbitek i w grudniu 1972 r. Słownik pracowników książki polskiej znalazł się na półkach księgarskich.

Ten pierwszy, najobszerniejszy, tom liczy 1043 dwuszpaltowe strony, zawiera ok. 3000, opatrzonych literaturą przedmiotu, biogramów autorstwa ok. 550 osób.

Dzieła słownikowego o tak szerokim zasięgu chronologicznym i zakresie tematycznym, jaki obejmował wydany Słownik pracowników ksiażki polskiej, literatura światowa dotycząca biografistyki księgoznawczej nie miała, zawierał on bowiem życiorysy osób zmarłych od czasów średniowiecza do początku lat siedemdziesiątych XX w., działających w Polsce i poza granicami naszego kraju oraz cudzoziemców pracujących na rzecz polskiej książki. Byli to przedstawiciele wszystkich profesji związanych z książką: kopiści i iluminatorzy rękopisów, drukarze, wydawcy, ilustratorzy, introligatorzy, księgarze, bibliotekarze, bibliografowie, bibliofile, bibliolodzy, działacze różnych towarzystw, stowarzyszeń i innych organizacji. Opublikowany Słownik stanowi podstawę źródłową wielu badań nad historią książki, bowiem poprzez działalność osób można poznać funkcjonowanie instytucji produkujących książki i je upowszechniających. Nadto Stownik prezentuje ludzi znanych, którzy zasłużyli się dla polskiej książki, oraz tych zagrożonych zapomnieniem, których praca przyczyniła się do rozwoju kultury książki w historycznych granicach Polski i na obczyźnie.

Prace nad kolejnym tomem Słownika pracowników książki polskiej kontynuowano w łódzkiej Redakcji (dwie osoby) przy udziale członków Komitetu Redakcyjnego (14 osób) już od 1973 r. Ułatwiły je przyjęte uprzednio założenia metodologiczne doboru haseł, ich wielkości oraz redagowania tekstów, ujednolicenia konstrukcji biogramów (nagłówka, treści, bibliografii załącznikowej), a także istniejący - stale poszerzany - warsztat i doświadczenie, jakie zyskał zespół redakcyjny działający nadal pod kierunkiem I. Treichel. Mimo to prace przedłużały się. Zintensyfikowano je dzięki pomocy dyrektor BUŁ prof. Heleny Więckowskiej (oddelegowała kilkoro bibliotekarzy do Redakcji) i dyrektora Instytutu Bibliotekoznawstwa Uniwersytetu Wrocławskiego prof. Bronisława Kocowskiego oraz jego następców, którzy włączyli Słownik do programu Instytutu realizującego problem węzłowy „Polska kultura narodowa, jej tendencje rozwojowe i percepcja” w ogólnokrajowym planie prac naukowo-badawczych.

W 1986 r. PWN opublikowało pierwszy nienumerowany Suplement do Stownika, uzupełniający go w tym samym zakresie o ok. 550 nowych 
biogramów pióra ok. 100 autorów . Natomiast zmienił się zasięg chronologiczny: uwzględniono przede wszystkim życiorysy osób zmarłych w latach 70. i 80. XX w., choć znalazły się także postacie działające od XIII w. niezamieszczone w tomie podstawowym.

W Suplemencie zamieszczono więcej niż w Stowniku haseł tzw. „sygnalizacyjnych", niepodających pełnych danych biograficznych, bowiem nie udało się ich pozyskać, ale ponieważ chodziło o osoby warte przypomnienia, takie „okrojone" życiorysy mają wskazywać na potrzebę dalszych badań i poszukiwań, zwłaszcza w zakresie źródeł regionalnych. Obok części biograficznej Suplement zawiera obszerny indeks alfabetyczny osób i instytucji związanych z historią książki polskiej wymienionych w Stowniku i Suplemencie; uwzględniono również drukiem kursywnym nazwiska autorów biogramów. Sporządzenie dwu indeksów - następnie połączonych - zajęło wiele czasu. Słownik indeksowały w latach 1973-1974 cztery osoby z BUŁ i dwoje członków Redakcji, natomiast Suplement tylko redaktorzy: H. Tadeusiewicz i I. Treichel, która opracowała koncepcję wspólnego indeksu tzw. krzyżowego do obydwu tomów oraz system graficznych odnośników kierujących do właściwych tomów publikacji. Indeks stanowi dla czytelników wielkie ułatwienie w pozyskaniu i wykorzystaniu zawartych w słownikowych biogramach informacji o ludziach i instytucjach.

Instytucje księgoznawcze włączono w alfabet, grupując pod hasłami: Biblioteki, Drukarnie, Drzeworytnie, Introligatornie, Księgarnie, Papiernie, Pracownie Iluminatorskie, Skryptoria, a także: Stowarzyszenia, Towarzystwa, Związki. Wydawnictwa odnajdziemy w połączeniu z drukarniami lub księgarniami - w zależności od nakładcy (drukarz czy księgarz). W obrębie instytucji zastosowano układ alfabetyczny miejscowości, w których one działały, a następnie - według ich nazw albo nazwisk właścicieli.

Tak pomyślany i opracowany indeks spowodował skupienie wszystkich materiałów zawartych w Słowniku i Suplemencie odnoszących się do osób i instytucji.

To, że pierwszy tom Słownika ukazał się bez indeksu (na ten brak wskazywano w recenzjach), stanowiło skutek prozaicznej decyzji - nieprzyznania PWN dodatkowego przydziału papieru. Redakcja postanowiła więc opublikować tylko część biograficzną w przekonaniu, że połączony indeks zamieści w planowanym suplemencie. I tak też się stało.

Rok po ogłoszeniu drukiem pierwszego Suplementu, w toku prac nad drugim, dzieło swojego życia osierociła redaktor I. Treichel (zm. 4 XII 1987 r.) $)^{9}$. Ponieważ drugi członek Redakcji - H. Tadeusiewicz była zatrudniona na stanowisku docenta w Katedrze BiIN UŁ, Stownik został bez pracowników.

Zob. Stownik pracowników ksiązki polskiej. Suplement, red. I. Treichel, Warszawa-Łódź 1986.

9 Zob. H. Tadeusiewicz, Irena Treichel (1918-1987), „Roczniki Biblioteczne” 1988, z. 2, s. 367-371; taż, Irena Treichel jako redaktor „, Stownika pracowników książki polskiej”, „Przegląd Biblioteczny" 1989, z. 2, s. 101-109. 
W tej sytuacji dyrekcja BUŁ skierowała do prac redakcyjnych kustosza dr. Jerzego Tyneckiego. Po jego śmierci (3 I 1992 r.), w porozumieniu z dyrektorem dr. Janem Janiakiem, H. Tadeusiewicz, kierująca wówczas Katedrą, uzyskała zgodę Senatu UŁ na przeniesienie Redakcji Słownika do Katedry; Rektor powołał badaczkę w 1992 r. na kierownika Pracowni Stownika pracowników ksiązki polskiej, w której znalazły miejsce wszystkie materiały, warsztat, kartoteki w pudłach i blokach katalogowych. Powołano wówczas zespół redakcyjny w składzie: H. Tadeusiewicz (przewodnicząca), Bogumił Karkowski (sekretarz), Jadwiga Konieczna, Magdalena Kwiatkowska - doktorzy zatrudnieni w Katedrze - oraz mgr Jolanta Soboń (pomoc techniczna) - także pracownik Katedry.

Odtąd intensywnie prowadzone prace, trwające osiem lat, doprowadziły do opublikowania w 2000 r. Suplementu II ${ }^{10}$, którego edytorem było SBP w Warszawie (PWN zrezygnowało z praw do tytułu); ukazał się jako nr 39 recenzowanej serii „Nauka-Dydaktyka-Praktyka” (recenzenci: prof. dr hab. Janusz Kapuścik i dr hab. Bronisława Woźniczka-Paruzel). Wydany tom zawierał 392 biogramy pióra 113 autorów i liczył 205 s. wraz z własnym indeksem. Nowy edytor w porozumieniu z Redakcją zachował dwuszpaltowy druk, układ graficzny, budowę nagłówków i bibliografii oraz konstrukcję indeksu osób i instytucji. Wszystkie hasła były autoryzowane, co pozwoliło teksty podpisać. Nie zmienił się także zakres tematyczny biogramów, natomiast ich zasięg chronologiczny przesunięto do końca XX w., znalazły się więc w Suplemencie II życiorysy osób zmarlych w latach osiemdziesiątych i dziewięćdziesiątych, np. I. Treichel (1987) ${ }^{11}$, Józefy Słomczewskiej (1989) ${ }^{12}$, Mirona Kołakowskiego $(1993)^{13}$, Domicelli Staniszewskiej (1997) ${ }^{14}$ czy Jadwigi Orzechowej (1999) ${ }^{15}$.

Kolejnych dziesięć lat zajęło przygotowanie Suplementu III. Ukazał się w 2010 r., podobnie jak poprzedni tom - w Wydawnictwie SBP, w serii „Nauka-Dydaktyka-Praktyka” (nr 121). W skład Komitetu Redakcyjnego serii wchodziła H. Tadeusiewicz - przewodnicząca Zespołu redagującego Suplement III, do prac którego zaprosiła J. Konieczną, M. Kwiatkowską,

10 Zob. Stownik pracowników książki polskiej. Suplement II, red. H. Tadeusiewicz z udziałem B. Karkowskiego, Warszawa 2000.

11 Zob. H. Tadeusiewicz, Treichel Irena (6 VII 1918 Rypin, woj. warszawskie - 4 XII 1987 Łódź), [w:] tamże, s. 164-165.

12 Zob. M. Czarnowska, Stomczewska-Kornecka Józefa (20 III 1907 Warszawa - 2 II 1989 tamże), [w:] tamże, s. 145-146.

13 Zob. Z. Żmigrodzki, Kolakowski Miron (23 I 1911 Czesstochowa- 9 I 1993 tamże), [w:] tamże, s. 80.

14 Zob. Z. Sokół, Staniszewska Domicella (6 IV 1939 Książnice k. Lublina - 17 II 1997 Mielec), [w:] tamże, s. 151.

15 Zob. Z. Sokół, Orzechowa Jadwiga Eugenia (13 X 1927 Przemyśl - 2 V 1999 Rzeszów), [w:] tamże, s. 118. 
M. Rzadkowolską i A. Walczak-Niewiadomską (pełniła odpowiedzialną funkcję sekretarza, zastępując zmarłego 1 VI 2004 r. B. Karkowskiego). Zamysł stopniowego „odmładzania” Redakcji i włączanie koleżanek, chętnych do działania, posiadających już stopnie naukowe i dorobek publikacyjny, miał na celu wdrożenie ich do działań „słownikowych” - merytorycznych, formalnych, technicznych, aby w trakcie pracy zyskały potrzebne doświadczenie.

Ogłoszony Suplement III zawiera 404 biogramy ,pracowników książki polskiej" autorstwa 198 osób; tom, wraz z indeksem, liczy 452 strony ${ }^{16}$. Hasła wiążące się oznaczono symbolami graficznymi, stosowanymi we wcześniej wydanych tomach Stownika; Redakcja we Wstępie wyjaśniła czytelnikom system owych oznaczeń ${ }^{17}$. Był on nie tylko powiązaniem łączących się merytorycznie haseł biograficznych, lecz spełniał także rolę kontrolną. Na przykład jeśli w haśle drukarza „A” podano informację, że kupił oficynę w 1890 r. od drukarza „B”, to w życiorysie tego drugiego musiała pojawić się wiadomość, że w 1890 r. sprzedał swój warsztat typograficzny drukarzowi „A”; w razie jakiejś rozbieżności faktów czy dat trzeba było ustalić właściwe dane. Taka dodatkowa kontrola gwarantowała poprawność merytoryczną i faktograficzną; należała do obowiązków osoby opracowującej teksty redakcyjnie. Kontrola dotyczyła nie tylko haseł łączących się w obrębie pojedynczego tomu, lecz obejmowała także te opublikowane w kolejnych tomach, co stanowi niewątpliwie ich dodatkową wartość

Suplement III do Stownika uwzględnił biogramy ,pracowników książki polskiej” działających w stuleciach XVIII-XX, zawiera też życiorysy osób zmarłych w pierwszym dziesięcioleciu XXI w.; byli to np. Barbara Lis $(2001)^{18}$, Kazimierz Walczak (2004) ${ }^{19}$, Janina Obmińska (2006) ${ }^{20}$, Maria Salomea Wielopolska (2007) ${ }^{21}$, Kazimiera Zabrocka (2008) ${ }^{22}$ i Jadwiga Andrzejewska $(2010)^{23}$.

Z każdym kolejnym suplementem zmieniały się proporcje osób reprezentujących poszczególne grupy zawodowe. W porównaniu z tomem pod-

\footnotetext{
16 Zob. Słownik pracowników książki polskiej. Suplement III, red. H. Tadeusiewicz, Warszawa 2010.

Zob. Redakcja, Wstęp, w: tamże, s. 5.

18 Zob. E. Pawlicka, Lis Barbara (2 X 1932 Łódź - 11 IV 2001 tamże), [w:] tamże, s. 172-173.

19 Zob. M. Rzadkowolska, Walczak Kazimierz (15 I 1941 Dubiecko, pow. przemyski - 19 VIII 2004 Łódź), [w:] tamże, s. 289-290.

20 Zob. E. Czerniejewska, Obmińska Janina (28 V 1928 Stanistawów - 5 X 2006 Wroctaw), [w:] tamże, s. 209.

${ }_{21}$ Zob. T. Jasińska, A. Łozowska, C. Judek, Wielopolska Maria Salomea (1 III 1916 Stuttgart, Niemcy - 30 IX 2006 Szczecin), [w:] tamże, s. 296-297.

22 Zob. A. Stępień, E. Skibińska, Zabrocka Kazimiera z d. Plucińska (31 I 1928 Żyrardów - 1 I 2008 Warszawa), [w:] tamże, s. 308.

23 Zob. H. Rusińska-Giertych, Andrzejewska Jadwiga z d. Żamojto (20 XI 1923 Dąrowa, pow. Oszmiana, obecnie Białoruś - 24 I 2010 Wrocław), [w:] tamże, s. 9-10.
} 
stawowym malała liczba drukarzy, wydawców, introligatorów, bibliofilów, a życiorysy kopistów i malarzy rękopisów (iluminatorów, miniaturzystów, rubrykatorów) w suplementach już się nie pojawiły. Wzrastała natomiast sukcesywnie liczba biogramów bibliotekarzy, zwłaszcza bibliotek publicznych i akademickich. Zwiększała się również reprezentacja bibliologów, pracowników naukowych instytutów uniwersyteckiego kształcenia bibliotekarzy, pracowników informacji naukowej (teoretyków i praktyków), ilustratorów i grafików książkowych. Przy przygotowywaniu Suplementów, zwłaszcza III i IV, zadbano o uwzględnienie Polaków działających na rzecz naszej książki za granicą, np. w Londynie, Paryżu i Rapperswilu.

Normalną, choć smutną koleją rzeczy zabiegaliśmy, aby odnotować w słownikowym wydawnictwie zmarłych autorów życiorysów w nim zamieszczonych, znalazły się w nim także biogramy członków Redakcji i Komitatu Redakcyjnego, współpracowników i recenzentów. Jest ich już wielu.

Jeśli zliczyć hasła zamieszczone w pięciu tomach Stownika wydanych w latach 1972-2016, należy odnotować ogółem 4842 biogramy „pracowników książki polskiej” żyjących i działających od XI do XXI w., pióra ok. 1100 autorów - to imponujący wynik! Osiągnięto go dzięki gronu oddanych redaktorów i autorów z różnych ośrodków bibliotecznych w kraju, zaangażowanych w realizację wspólnego dzieła, którym udało się stworzyć dobrą, przyjazną atmosferę towarzyszącą tej pracy.

Kolejne tomy Słownika pracowników książki polskiej służą już 45 lat trzeciemu pokoleniu Polaków w ich pracy zawodowej, naukowej, publikacyjnej, stanowią cenne źródło do badań nad historią książki i bibliotek w naszym kraju.

Zainteresowani poza opublikowanymi tomami mają także do dyspozycji kartoteki, archiwum i inne materiały (od 1992 r. w Pracowni Stowni$k a$ w Katedrze BiIN UŁ). Są to np. teksty życiorysów, których z różnych względów nie przeznaczono do druku, oraz dokumenty biograficzne i ikonograficzne (fotografie osób, budynków, wnętrz, urządzeń) znajdujące się w opracowanym archiwum Stownika (niekiedy cytowanym w bibliografii do zamieszczonych życiorysów). Powstające w trakcie prac nad Stownikiem archiwum i cały warsztat stanowią niejako „uboczne”, ale jakże cenne dobro - służące redaktorom, autorom, współpracownikom i pozostałym osobom informacjami, jakich nigdzie indziej nie uzyskają, a które udostępnialiśmy bez ograniczeń.

Słownik pracowników ksiązki polskiej wykorzystywano, jak pisałam, przy tworzeniu książek, artykułów, prac magisterskich i doktorskich, ale i on sam był przedmiotem ogłaszanych drukiem omówień. W 1985 r. na łamach „Przeglądu Bibliotecznego" ukazał się artykuł pióra I. Treichel poświęcony przebie- 
gowi prac nad realizacją podstawowego tomu Stownika, organizacji redakcji, koncepcji doboru hase ${ }^{24}$, a tworzący się warsztat prac nad publikacją przedstawiła w „Listach Bibliofilskich”25. Suplement do Stownika stał się przedmiotem jej artykułu opublikowanego w 1979 r. w „Przeglądzie Bibliotecznym”26. Ogólnie o Stowniku pisała w „Biuletynie Głównej Biblioteki Lekarskiej” H. Tadeusiewicz ${ }^{27}$, o drugim suplemencie informowała w 1999 r. w „Przeglądzie Bibliotecznym" "28, o suplemencie trzecim - w książce Bibliologia. Problemy badawcze nauk humanistycznych wydanej w 2007 r. ${ }^{29}$ oraz w 2010 r. w księdze pamiątkowej poświęconej profesorowi Krzysztofowi Migoniowi ${ }^{30}$. Rok 2011 przyniósł wnikliwą recenzję trzeciego suplementu przygotowaną przez dr hab. Marią Kocójową i ogłoszoną w „Przeglądzie Bibliotecznym” ”. W tymże roku ukazał się tekst A. Walczak-Niewiadomskiej omawiający udział H. Tadeusiewicz w pracach nad Stownikiem, zamieszczony w księdze pamiątkowej jej dedykowanej ${ }^{32}$ oraz artykuł pióra H. Tadeusiewicz, M. Rzadkowolskiej i A. Walczak-Niewiadomskiej o działalności Pracowni Słownika pracowników książki polskiej jako Centrum Badań Biografistyki Księgoznawczej w Polsce, opublikowany w książce pt. Bibliologia i informatologia ${ }^{33}$. Wymienione prace

24 Zob. I. Treichel, Stownik pracowników ksiązki polskiej. Przebieg prac nad realizacja publikacji, ich organizacja i metody, „Przegląd Biblioteczny” 1985, z. 3-4, s. 439-457.

${ }_{25}$ Zob. taż, Warsztat Stownika pracowników książki polskiej w Bibliotece Uniwersyteckiej $w$ Łodzi, „Listy Bibliofilskie” 1983, s. 9-13.

26 Zob. taż, Suplement do „Stownika pracowników książki polskiej”, „Przegląd Biblioteczny” 1979, z. 3, s. 329-332.

27 Zob. H. Tadeusiewicz, Stownik pracowników ksiażki polskiej 20 lat w stużbie nauki, „Biuletyn Głównej Biblioteki Lekarskiej” 1994 (druk. 1995), nr 349, s. 47-56.

28 Zob. taż, ,,Stownik pracowników ksiązki polskiej”. Suplement II, „Przegląd Biblioteczny” 1999, z. 1 i 2, s. 81-82. Zob. też taż, Komunikat o suplemencie II „, Stownika pracowników ksiażki polskiej, [w:] Rozwój prowincji naszej: życie społeczno-kulturalne ośrodków lokalnych ziem polskich $w$ dobie popowstaniowej 1864-1914: [materiały z Ogólnopolskiej Konferencji Historyków Prasy i Kultury, Skarżysko Kamienna 29-30 października 1992 r.], pod red. M. Adamczyka i A. Notkowskiego, Kielce-Warszawa 1993, s. 347-349.

29 Zob. taż, Prace nad III Suplementem ,,Stownika pracowników książki polskiej”, [w:] Bibliologia. Problemy badawcze nauk humanistycznych, pod red. D. Kuźminy, Warszawa 2007, s. 396.

30 Zob. O dwu stownikach realizowanych w Katedrze Bibliotekoznawstwa i Informacji Naukowej Uniwersytetu Lódzkiego, [w:] Książka zawsze obecna. Prace ofiarowane profesorowi Krzysztofowi Migoniowi, [kom. red. B. Bieńkowska in.], Wrocław 2010, s. 107-110.

31 Zob. M. Kocójowa, Stownik pracowników książki polskiej, „Przegląd Biblioteczny” 2011, z. 3, s. 341-355.

32 Zob. A. Walczak-Niewiadomska, Udziat Profesor Hanny Tadeusiewicz w edycji Stownika pracowników książki polskiej, [w:] Ludzie i książki. Studia i szkice bibliologiczno-biograficzne. Księga pamiątkowa dedykowana profesor Hannie Tadeusiewicz, [red. E. Andrysiak; współpr. red. J. Konieczna, A. Walczak-Niewiadomska, M. Rzadkowolska], Łódź 2011, s. 13-16.

33 Zob. H. Tadeusiewicz, M. Rzadkowolska, A. Walczak-Niewiadomska, Pracownia ,,Stownika pracowników książki polskiej” jako Centrum Badań Biografistyki Księgoznawczej w Polsce, [w:] Bibliologia i informatologia, pod red. D. Kuźminy, Warszawa 2011, s. 167-172. Zob. też H. Tadeusiewicz, Prosto do celu, [w:] Moja droga do nauki, red. M. Pawlik, Łódź 2011, s. 227-238. 
zamieszczone są w załączonej Bibliografii. Wspomnieć jeszcze wypada, iż Redakcja ogłaszała w lokalnej prasie łódzkiej, w ogólnopolskich czasopismach bibliotekarskich, bibliologicznych i innych apele o nadsyłanie propozycji haseł lub gotowych biogramów do kolejnych tomów wydawnictwa.

Tak przebiegały, w skrócie przedstawione, prace zmierzające do opublikowania Stownika pracowników książki polskiej - od tomu podstawowego w 1972 r. do Suplementu IV w 2016 r.

Wraz z nowo wydanym tomem odchodzę, po 52 latach działalności, z Redakcji i Pracowni Stownika. Planowany Suplement $V$ będą realizować młodsi, których starałam się dobrze przygotować do pracy i którzy wykorzystując zdobytą wiedzę i doświadczenie, poprowadzą dalej zaczęte przed siedemdziesiącioma laty dzieło, będące chlubą biografistyki księgoznawczej w Polsce*.

\section{Streszczenie}

W artykule zaprezentowano wydawnictwo z zakresu biografistyki księgoznawczej pt. Stownik pracowników ksiązki polskiej, realizowane w Uniwersytecie Łódzkim - najpierw w Bibliotece Uniwersyteckiej w Łodzi (od 1958 r.), następnie - w Katedrze Bibliotekoznawstwa i Informacji Naukowej UŁ (od 1992 r.).

W latach 1972-2016 ukazał się tom podstawowy Stownika (1972) i cztery suplementy $(1986,2000,2010,2016)$. Redaktorami naukowymi były kolejno: I. Treichel, H. Tadeusiewicz, M. Rzadkowolska. Planowany piąty suplement poprowadzi A. Walczak-Niewiadomska. Edytorem Słownika było Państwowe Wydawnictwo Naukowe (tomy z 1972 i z 1986 r.) i Stowarzyszenie Bibliotekarzy Polskich (tomy z 2000, 2010 i 2016 r.).

Autorka omówiła także zakres tematyczny i zasięg chronologiczny Stownika, jego warsztat (publikacje towarzyszące, kartoteki, archiwum); podała ogólna liczbę haseł (4842) i autorów (1100), podkreśliła znaczenie wydawnictwa dla biografistyki księgoznawczej oraz dziejów książki w Polsce.

Słowa kluczowe: słownik biograficzny - biografistyka księgoznawcza Słownik pracowników książki polskiej - historia książki.

* Dziękuję bardzo obecnym i byłym (także pamięci zmarłych - pożegnałam ich opublikowanymi wspomnieniami) redaktorom i autorom Stownika za czas wspólnej pracy, która wiele mnie nauczyła i przyniosła pełną satysfakcję zawodową i naukową. 


\section{Summary}

\section{On dictionary publication from the field of the book studies' biographies}

The article presents the dictionary publication from the field of the book studies' biographies Stownik pracowników ksiażki polskiej (Biographical Dictionary of the Workers of the Polish Book) prepared in the University of Łódź - first in University Library in Łódź (from 1958) then in the Chair of Library and Information Science UŁ (from 1992).

In the years 1972-2016 there were published the core volume of the $B i$ ographical Dictionary (1972) and 4 supplements (1986, 2000, 2010, 2016). Their scientific editors were - as follows - I. Treichel, H. Tadeusiewicz, M. Rzadkowolska. The next, planned $5^{\text {th }}$ supplement will be edited by A. Walczak-Niewiadomska. The Dictionary was published by the National Scientific Publishers PWN (volumes from 1972 and from 1986) and The Polish Librarian's Association (volumes from 2000, 2010 and 2016).

The author discussed also subject and chronological scope of the Dictionary as well as its additional sources (associating publications, archive, card file); provided readers with number of its entries (4842) and authors (1100), underlined meaning of the publication for the field of book studies' biographies and for the book history in Poland.

Keywords: biographical dictionary - book studies' biographies - Biographical Dictionary of the Workers of the Polish Book - history of the book. 